\title{
Exploring Students' Perception and Belief of Extensive Reading Program in Improving Reading Ability and Language Competences
}

\author{
Winda Ari Anggraini \\ SMA Negeri 1 Manggar \\ East Belitung \\ Indonesia \\ windaarianggraini@gmail.com
}

Citation: Anggraini, Winda Ari. (2020). Exploring students' perception and belief of extensive reading program in improving reading ability and language competences. Notion: Journal of Linguistics, Literature, and Culture, Vol 2(1), p. 42-50. DOI: http://doi.org/10.12928/notion.v2i1.10263

\section{Article Info}

Article History

- Article Received $12^{\text {th }}$ September 2019

- Article Accepted $1^{\text {st }}$ May 2020

\section{Keywords}

students' perception

belief

extensive reading

reading ability

language competence

\section{ABSTRACT}

The aim of this research was to investigate students' perception toward a small-scale project of extensive reading (ER) program. ER is believed can improve many aspects of language skills, including vocabulary, reading speed, listening, speaking, and writing[4][6]. Therefore, research participants were also asked about their view on reading ability and other linguistic competences improvement. This research utilized case study specifically focused on three students who showed outstanding progress through the project, using semi-structured interview for data collection. The paper concludes with positive results for both students' perception and their reading ability and language competence. 


\section{Anggraini, Winda Ari \\ Exploring Students' Perception and Belief of Extensive Reading Program in Improving Reading \\ Ability and Language Competences}

\section{INTRODUCTION}

Recently the government has announced a literacy program, namely Gerakan Literasi Sekolah (School Literacy Program). It aims to create a literate generation that continuously read and write by involving the headmasters, teachers, and all the stakeholders in the school. The rationale behind this program is to reduce the low level of reading interest of Indonesian students. This can be proved by the result of Progress in International Reading Literacy Study (PIRLS) in 2011, Indonesia was in the 45th out of 48th countries participated. Additionally, from Programme for International Student Assessment (PISA) in 2012, Indonesia was in 64th in reading skill from 65 countries participated[1].

To support the government's program on improving students' reading interest and ability, especially in reading English text, an ER program was created. Numerous studies have shown that ER is beneficial in a second language (L2) teaching reading [2][3][4][5][6][7]. However, the implementation of ER on a regular basis in schools is still limited and not applied by many teachers due to the number of sources and expenses needed[8]. Sometimes, it is also considered as time-consuming because ER requires a long span of time to be realized. In this school, however, ER was conducted as an extracurricular activity to underpin English class and English annual competition. The program was supported by the school and local library where students involved should read minimum one book for two weeks in the beginning. Students were instructed to write a reading list and journal to be monitored by the teacher. They also had a group discussion once a week as a postreading activity.

Many studies have investigated L2 teachers' attitudes on ER and how effective it is[9][10][11], but students' views are rarely heard. That is why this case study focused on answering these following questions: (1). What is the students' perception about extensive reading? (2). To what extent the students believe extensive reading improve their reading ability and other linguistic competences?

\section{Teaching reading in $\mathbf{L} 2$ classroom}

In general, reading is a complex cognitive skill to decode printed texts involving "syntax, semantics, and discourse, and even to skills of text representation and integration of ideas with the reader's global knowledge"[12]. Grabe[13] classifies the notion of L2 reading based on its purposes and processes. $\mathrm{He}$ mentions these goals of reading bring to a different definition: reading for quick interpretation, reading to search for or combine information, to learn in depth, to evaluate, and to entertain. On the other hand, ten processes can define reading: rapid, efficient, comprehending, interactive, strategic, flexible, purposeful, evaluative, learning, and linguistic process. Reading is viewed as a set of integrated skills and processes involved to deal with different purposes of reading[13].

Reading in L2 is defined as 'a dynamic relationship' and 'an active process' to illustrate how readers make sense of a text and combine previous knowledge and information in the text respectively[14]. Koda[15] differentiates first language (L1) and L2 readers regarding the cross-linguistic process. L1 learners work to decode written text with vocabulary while L2 readers emphasize on the linguistic foundation. L2 readers need more knowledge as a threshold to establish their L1 ability into L2[16]. In addition, Wallace[17] expands reading as "a social, critical and interpretative process rather than as a skill or set of skills". Reading also employs students' metacognition to understand and control their critical thinking toward texts.

Teaching reading in an L2 classroom means teachers facilitate students to become a skilled reader. Grabe and Stoller[18] explain a series of abilities that students should develop for becoming skillful readers: efficient word recognition, grammatical sensitivity, comprehension, activation of prior knowledge, effective inferences, and fluency. Teachers necessitate examining these reading abilities in their teaching instructions. But teaching reading may focus on specific reading skills and differ based on institutional goals and expected students' outcomes[18]. Moreover, students' reading outcomes 
are affected by many factors beyond teaching syllabus and classroom instruction such as students' proficiency, access to resources, teachers' belief and abilities, reading attitude and reading habit in one area.

There are two major approaches to teaching reading, intensive reading (IR) and ER[19]. IR is conducted in the classroom with the teacher's guidance and arranged activities. Here, students usually interact with short texts. Reading materials are also mostly selected by the teacher with predetermined topics related to curriculum. The purpose is to understand the texts in detail and how the meaning is produced, as well as to develop reading skills. It can also help with faster awareness of certain language structures and vocabulary acquisition. Teachers can establish reading strategies through IR. However, students can only obtain substantial practice for applying their reading strategies through ER.

Even though IR and ER differ in some ways, it is important not to see them as opposition. They can complement each other[6]. The implementation of IR and ER should notice the three elements of post method pedagogy: particularity, practicality, and possibility. IR is supposed to be conducted in every L2 classroom, while ER considers the situation of a particular educational institution. It is crucial to concern on the availability of resources, teachers' attitude and willingness, and socio-economic background of a school. Moreover, ER should practically consider students' learning need.

\section{Extensive reading: Definition, principles and activities}

Davis[3] defines an ER program as a part of English class involving school library support, "in which pupils are given the time, encouragement, and materials to read pleasurably, at their own level, as many books as they can, without the pressures of testing or marks". Therefore, students are encouraged to read as many books as possible for pleasure. There is no evaluation for their reading. William and Moran[20] call it one of reading styles along with skimming, scanning, and IR. On the other hand, Day and Bamford[4] defines ER as an approach which students read in L2 and like it. Furthermore, they refer to 'a process in which students 'willing to engage... [with] a lot of extended texts for a variety of reasons' (p. 7). Then, ER is extended to a situation where students read a lot of materials on their level in a new language; they read for general, for overall meaning, and for information at one with enjoyment[21]. It is projected to build positive attitude a toward reading and to develop good reading habits[6]. The concept of ER is exposing students to an input-rich and enjoyable environment, with the intention that their language knowledge will improve and their enthusiasm to learn will develop naturally.

Even though, there is no precise number of books to be read, the successful of ER can be measured by following ten principles of ER proposed by Day and Bamford[22]. The principles include: Reading materials shall be easy and available in a wide range of topics. ER requires a large number of books' selection or other sources to read according to students' level. Unlike IR which goes in line with fixed topics, ER offers a wide variety of materials, ranging from different topics. The materials consist of graded readers which are books that have been designed and had the language level simplified to adjust to L2 learners; and authentic materials that are not specifically for teaching purposes. Moreover, they can be academic or popular authentic materials[23], such as novels, short stories, magazines, or subtitled movies.

Then, students can choose anything to read based on their interests. If they find a text is too difficult, they may change to easier ones. ER focuses on the amount of time spent in reading, the more learners read, the better they achieve. Teachers can help to provide extensive resources outside of the classroom by the support of school library or local library. The purpose of reading varies from obtaining general knowledge, pleasure and information. By doing ER, students are not assigned to read for doing tasks or homework. Reading is encouraged for its own reward which is not followed by comprehension questions after that. It is considered as an individual and silent process to enjoy. Even though teachers may provide a few post-reading activities, they are only meant for monitoring students' track and attitude. 


\section{Anggraini, Winda Ari \\ Exploring Students' Perception and Belief of Extensive Reading Program in Improving Reading \\ Ability and Language Competences}

The role of teachers in ER is to introduce and guide students through the process. The individual nature of ER can help teachers to build a noncompetitive atmosphere of reading community. Teachers explain the purpose in the beginning then guide students. They may also monitor students' reading progress by providing journal. Another way to keep the students' reading track is providing postreading activity. The activities can be a group discussion, a book report, or storytelling. In addition, teachers become role models to show how important reading is.

Day and Bamford[4] mention ER can be included in an L2 curriculum in at least four broad ways: as a separate, stand-alone lesson, a part of an existing reading class, as a non-credit audition to an existing course, and as an extracurricular activity. The first three activities are functioned as an extension of reading in L2 classrooms, where learners might get scored or not. Unlike those programs, the latter is extracurricular. Here, students who are interested in, with different level of ability may join. Like other kinds of students' extracurricular, it is aimed to facilitate students' interest. Students gather after school regularly, for example, once a week.

\section{METHODOLOGY}

\section{a. Research Approach}

This research adopted a case study because it permitted to focus on one particular instance[24], i.e. three students who showed continuous progresses and outstanding performances in English from an ER program. Furthermore, Denscombe[25] describes the rationale behind concentrating on one individual case is to obtain insights in a wider implication. 'The aim is to illuminate the general by looking at the particular'.

\section{b. Data collection}

Data were collected by conducted a semistructured interview. It was carried out to gain an indepth insight of the students' perspectives and experiences on ER program they followed[26]. The questions were developed based on Day and Bamford[4] ER evaluation model and de Morgado[8] research instrument. At first, the students were informed the purpose of the research and then was given an opportunity to speak in any languages that felt more comfortable. The interview was done separately for each participant and recorded. In addition, the participants were asked to collect some examples of their reading records from the first time they joined the program.

\section{c. Context}

The senior high school is located in the middle of busy town where there is a school library, a local library and also internet connection already available. Two years ago, an ER program was started in this school by a volunteer teacher from the United States, $\mathrm{Mr}$ John. He proposed ER as an extracurricular activity for preparing students for a national debate championship. The project was not big, like Book Flood in Fiji or Reading and English Acquisition Programme (REAP) in Singapore. He brought and introduced many English books, novels, and magazines to the students. ER was a complementary project targeting some students for supporting the school mission, but it followed the ten principles suggested by Day and Bramford[22]. Two teams consist of 6 students were selected as candidates for the competition and assigned to read as many texts as the students could. The preparation lasted for six months: the first three months, the teacher allowed the students to read based on their interest then continued to read topics related to debates. The teacher conducted post-reading activities regularly by asking students what they read and how they felt about it through reading journal and group discussions.

\section{d. Research participants}

Three students at twelfth grade of senior high school were selected as research participants. They showed excellent progress comparing to the rests of other students in the ER project. They have obtained better score in their English class rapport and performed in other English activities by becoming the representative of the school debate. For ethical concern, their names remain pseudonym. Elsa, Anna, and Kris were the school team sent to a district debate competition last year. Kris was defeated by other 
contestants, leaving Elsa and Anna for provincial level. After a series of matches, Elsa won the best speaker and went to the national debate. After winning all the matches, they admitted they still continually read for preparing university study and for enjoyment.

\section{RESULT AND DISCUSSION}

\section{a. Students' perception of extensive reading}

From the interview, three students explained how they changed their view during the program. At first, they said how ER was burdening because they have already studied many lessons per semester with lists of readings. For ER to be possible and to have good results, text selections should be within the students' reading competence. Because the teacher allowed the students chose the text to be read at home, they read enthusiastically and shared their experiences passionately. This finding is in line with the statement of Day and Bamford[21] that if ER is established by providing attractive reading materials and meeting with students' level, students will encounter reading for enjoyment and bring in the language learning rewards. Students will take pleasure in ER program because they can choose what they want to read. In ER students can access language in their comfort zone at their own pace. This activity allows them to consolidate their knowledge and how language works (Bell, 2001).

\section{E1sa:}

Then I started to be chill when I heard that John [their English teacher] let us choose our own books. I always like the story of murder and mystery. He suggested me to pick up some Agatha Christie and John Grisham books. They were very interesting to read.

Anna:

I prefer newspaper and magazines because I am an up to date person. I read them every day, but the amount depends on my mood. I read non-fiction books as well. Since I like. reading digital version, I also read various articles in a day. I should do this from years ago. It is fun to read in English, not as scary as I imagined.
Kris:

The order was frightening. At that moment, I preferred my games to books or serious printed texts. I always play computer games and learn English from the instructions or the storyline. Then, Mr John asked me to find books and magazines (or online version) related to games which changed my opinion. I can enjoy reading in my room or in front of my computer. I also read articles from related websites.

Despite the limitation of this small program and challenge from the students, the ER could be beneficial when students' attitude is positive, and their motivation is high. Green[27] believes ER planned and run by local teachers noticing suitable circumstances and incorporating interaction with the students shall work with confidence. In another question, they explained why they follow their teacher instruction devotedly although it was demanding. Nuttal[19] explains how students are more willing to read due to visible signs of their progress. When the long-term results of ER are apparent too late, something more immediate is needed to be an incentive.

\section{Elsa:}

I wanted to compete in a National debate, that is why I kept reading. That was my first competition ever in my life, and I really wanted to win. As a result, I won, local, regional, then national. All my struggle paid off.

\section{Anna:}

I wanted to debate as well as I could. I did not want to disappoint Mr John who spent time and money for us. So, I read many things to improve my knowledge to build arguments.

\section{Kris:}

I did not like it at first. Reading was not my style. But, looking how hard my friends to compete and represent our school has made me. I wanted to win with them. That's why I read then.

In this case, the students were motivated to follow the ER program based on their personal motive to win the competition followed. When students have a positive attitude to start reading new texts, their responses are improved. Therefore, they engage in 


\section{Anggraini, Winda Ari \\ Exploring Students' Perception and Belief of Extensive Reading Program in Improving Reading \\ Ability and Language Competences}

their reading because it is considered as a pleasurable and meaningful activity, not stressful.

\section{b. Students' belief of extensive reading in improving reading ability}

Day and Bamford[4] explain ER can influence reading ability regarding readers' attitude, improve their vocabulary, and other linguistic competences. However, Davis[3] mentions many benefits of ER can only be quantified after a long time. He explains how students cannot simply find it advantageous in the short term. Even though it was not described precisely about the number of books and texts involved in this project, it implies the continuous action of reading. The ER program for these students had started two years ago, at the beginning of their high school. It can be seen that the students perceived several benefits from the use of extensive reading. Here from the extracts are some examples:

\section{E1sa:}

To read more and read often has improved my vocabulary. I keep being curious about new words and find them after reading. It helped me in preparing my debate competition. I could build my arguments and choose words and expressions to be used.

The interview above shows that the student agreed with the statements that extensive reading helped them in developing their reading ability, concerning improving vocabulary and comprehension[28][29]. It is in line with $\mathrm{Hu}$ and Nation[30] who say reading comprehension can be achieved unless readers understand more than $80 \%$ vocabulary in the text. Koda[15] adds 'the concept of vocabulary threshold the boundary between having and not having sufficient knowledge-provides strong endorsement for the vocabulary supports comprehension view' ( $p$. 58). In the process of reading extensively, students read words which frequently appear in different texts. By this, students will be more familiar with the words, meanings, and usages in sentences, so their vocabulary recognition is developed. Vocabulary cannot be learned by a single exposure. ER provides students with multiple encounters with words, phrases, and expressions in context thus facilitating the progressive accretion of meanings.

\section{Anna:}

I continue reading although I find one or two difficult words. When I read the entire text, I think I already knew what the news meant. I guessed, and it worked most of the time.

As stated above that the student guessed the meaning of some words. Prediction is essential in making sense of meaning in a reading process. The student directed attention to difficult keywords and sentences then predicted the meaning based on the context. Prediction can activate schemata which consist of experience and background knowledge[19]. Schemata are used to interpret and understand the text. By presenting items in context, schemata make the deduction of meanings of unknown items easier. ER can "support the negotiation of meanings in texts, helps prevent the fossilisation of interlanguage structures, and provides contexts in which learners can encounter and debate ideas, and analyse and practise language features found in the texts"[27].

\section{Kris:}

I can say it enriches my vocabulary. Some words that I did not know before becoming more familiar. Reading various texts has helped me build useful knowledge. When we were in debate competition, some motions become easier to tackle. It is like we already had the knowledge from our reading so that we can express our ideas at that time.

Han and Anderson[31] mention aspects involved in describing an effective reading pedagogy. First, the activation of prior knowledge. As indicated before, ER can develop schemata. Students read various texts will enrich their knowledge. It will be beneficial for them when they read a new topic. The students attend closely to the main ideas of the text and more actively build connections with background knowledge to support coherence inferences. Then, a compelling reading cultivates and sustains vocabulary growth. In addition, reading speed is also becoming one of effective reading parameters. Researchers suggested that ER also contributes to reading speed development[2][32]. By doing ER, students are compatible with the ability to recognise words efficiently and automatically so that they may read faster. 


\section{Anna}

Honestly, reading many texts really helped me to improve my English since I kept doing it since two years ago. I feel I can read faster than I was in the first year of my high school. I read a book for two weeks, but now I can spend a week or less for a book with similarpages.

\section{c. Students' belief of extensive reading in improving language competences (writing, speaking, and listening)}

The aim of ER in this school was to prepare the students for a National Debate Competition. In a debate, different language skills are necessary: e.g. listening to other team arguments, writing their points of views, and then expressing their ideas. ER is believed to not only improve reading ability but also other language skills through a variety of reading exposure[4][6].

\section{Elsa:}

Speaking was always difficult for me. I did not speak that much before joining the debate and its preparation. It was like a miracle, once I debated, I talked a lot. I could say it is because I read many materials about it. I also practice speaking with friends via online chat or daily life. Talking about my score, I got A for all English lessons [receptive knowledge (reading, listening, and exam) and productive knowledge (writing and speaking)].

\section{Anna:}

I think reading makes me confident to write my arguments and rebuttals then speak it. While for listening, I also practised from other sources. You know NHK channel [Japanese English Channel]? I like watching that especially for program "Somewhere Street". I notice when she or he speaks English without any translation on it. I currently watch Arirang Channel from Korea which also uses English. Yeah, I improve my English through that ways. Well, A for both my English, the score is getting higher every year.

\section{Kris:}

Practices made me speak fluently. Well, sometimes if I didn't read about a topic in detail, I could not speak for 7 minutes [required time for building argument]. Reading more helped me speaking more. My English is getting better because I do many reading and other practices. Thanks, God. It's always $A$.

Despite reading ability, nearly all aspects of language competences, such as writing, speaking, and listening can be enhanced by ER[33]. Books and other sources provide a wealth of input in which students absorb or encounter for communicating ideas. Being exposed to various texts allows students to consolidate vocabulary and consider the structure of sentences. Moreover, in post-reading activities, students are encouraged to express their thought, ideas, and opinion about what they read in written or spoken form.

From the aforementioned answers, the students feel their language skills improved as they follow the ER. Here, the ER project prepared the students for a competition, therefore they were encouraged to write and speak during the program. They found that their language competences have been developed. But at the same time, the students also mentioned about other activities contribute to enhance their language skills. Yamashita (2008) urges ER may have an overall positive impact on L2 language skills in the long term, but it would be too optimistic to expect that all skills may show similar improvements over a limited period of time. Exposure to language input is believed to influence the language enhancement in general unconsciously. The students do ER as well as expose themselves to different materials for extensive listening and speaking at the same time.

\section{CONCLUSION}

Reading in L2 is challenging since the students also have issues with reading in their L1. It requires continuous effort from both L2 teachers and the students to start and keep reading as interesting daily activities. ER could be a promising starting point to do the transformation.

Successful ER program places on ongoing reading experiences. The longer the duration of the ER, the better the result will be, especially when reading has become a habit. ER is an individual activity that can develop students' learning autonomy because they read at their own pace depending on their levels and interests. ER allows them to choose their reading genre, not merely limited to lesson books or lesson 


\section{Anggraini, Winda Ari \\ Exploring Students' Perception and Belief of Extensive Reading Program in Improving Reading Ability and Language Competences}

related, but also various kinds of books and stories available both online and printed. ER also offers flexibility in time when the students are willing to read, and places where they feel comfortable and have positive atmosphere. Once they transform ER into a reading habit, they will become more interested in different types of texts which can be useful for L2 learning in general. ER can be a lifelong learning approach to language acquisition and intellectual growth[34]. ER will be beneficial to improve reading ability, to enrich vocabularies and also to develop other language competences, writing, listening, and speaking.

\section{REFERENCES}

[1] Kemendikbud. (2016). Desain Induk Gerakan Literasi Sekolah. Jakarta: Dirjen Pendidikan Dasar dan Menengah, Kemendikbud RI.

[2] Bell, T. (2001). Extensive reading: Speed and comprehension. The Reading Matrix, 1(1), p. 1-13.

[3] Davis, C. (1995). An expensive extravagance? ELT Journal, 49(4), p. 329-336.

[4] Day, R. \& Bamford, J. (1998) Extensive reading in the second language classroom. Cambridge: Cambridge University Press.

[5] Iwahori, Y. (2008). Developing reading fluency: A study of extensive reading in EFL. Reading in a Foreign Language, 20(1), p. 70-91.

[6] Renandya, W. A. (2007). The power of extensive reading. RELC Journal, 38(2), p. 133-149.

[7] Yamashita, J. (2008). Extensive reading \& development of different aspects of L2 proficiency. System, 36(4), p. 661-672.

[8] de Morgado, N. F. (2009). Extensive reading: Students' performance and perception. The Reading Matrix, 9(1), p. 31-43.

[9] Chang, A. C. \& Renandya, W. A. (2017). Current practice of extensive reading in Asia: teachers' perceptions. The Reading Matrix, 17(1), p. 40-58.
[10]Macalister, J. (2010). Investigating teacher attitudes to extensive reading practices in higher education: Why isn't everyone doing it? RELC Journal, 41(1), p. 59-75

[11]Mason, B. \& Krashen, S. (1997). Extensive reading in English as a foreign language. System, 25(1), p. 91-102.

[12]Nassaji, H. (2011). Issues in second language reading: Implications for acquisition and instruction. Reading Research Journal, 46(2), p. 173184.

[13]Grabe, W. (2009). Reading in a second language: Moving from theory to practice. Cambridge: Cambridge University Press.

[14]Hedge, T. (2001). Teaching and learning in the language classroom. Oxford: Oxford University Press.

[15]Koda, K. (2005). Insights into second language reading: a cross-linguistic approach. Cambridge: Cambridge University Press.

[16]Wallace, C. (2001). Reading, in R. Carter \& D. Nunan (eds.). Teaching English to speaker of other language. Cambridge: Cambridge University Press, p. 22-27.

[17]Wallace, C. (2003). Critical reading in language education. Basingstoke: Palgrave.

[18]Grabe, W.P. \& Stoller, F.L. (2011). Teaching and researching: Reading ( $2^{\text {nd }}$ ed). Harlow: Pearson Education Limited.

[19]Nuttal, C. (1996). Teaching reading skills in a foreign language. Oxford: Heinemann.

[20]William, E. \& Moran, C. (1989). Reading in a foreign language at intermediate \& advanced levels with particular reference to English. Language Teaching, 22(4), p. 217-228.

[21]Day, R. R. \& Bamford, J. (2004). Extensive reading activities for teaching language. Cambridge: Cambridge University Press. 
[22]Day, R. \& Bamford, J. (2002). Top ten principles for teaching extensive reading. Reading in a Foreign Language, 14(2), p. 136-141.

[23]Hwang, C.C. (2005). Effective EFL education through popular authentic materials. Asian EFL Journal, 7(1), p. 90-101.

[24]Thomas, G. (2013). How to do your research project: a guide for students in education and applied social sciences $2^{\text {nd }}$ ed). London: Sage.

[25]Denscombe, M. (2003). The good research guide: for small-scale social research projects ( $\left.2^{\text {nd }} \mathrm{ed}\right)$. Maidenhead: Open University Press.

[26]Jognson, G. (2002). Teachers challenging the status quo in the research interview. Journal of Education for Teaching: International Research and Pedagogy, 28(3), p. 275-278.

[27] Green, C. (2005). Integrating extensive reading in the task-based curriculum. ELT Journal, 59(4), p. 306-311.

[28]Horst, M. (2005). Learning second language vocabulary through extensive reading: A measurement study. The Canadian Modern Language Review, 61, p. 355-382.

[29]Pigada, M. \& Schmitt, N. (2006). Vocabulary acquisition from extensive reading: A case study. Reading in a Foreign Language, 18(1), p. 1-28.

[30] Hu, M. \& Nation, P. (2000). Unknown vocabulary density and reading comprehension. Reading in a Foreign Language, 13(1), p. 403-430.

[31]Han, Z. \& Anderson, N. J. (2009). Second language reading research and instruction: crossing the boundaries. Ann Arbor: University of Michigan Press.

[32]Tanaka, H. \& Stapleton, P. (2007). Increasing reading input in Japanese high school EFL classrooms: An empirical study exploring the efficacy of extensive reading. The Reading Matrix, 7(1), p. 115-131.

[33]Elley, W. B. (1998). Raising literacy levels in third world countries: A method that works. Culver City: Language Education Associates.
[34]Krashen, S. D. (2004). The power of reading: Insights from the research: Insights from the research ( $\left.2^{\text {nd }} \mathrm{ed}\right)$. Portsmouth: Heinemann. 